\title{
Human carbonic anhydrase II as host protein for the creation of artificial metalloenzymes: the asymmetric transfer hydrogenation of imines $\uparrow$
}

Received 22nd April 2013

Accepted 31st May 2013

DOI: $10.1039 / c 3 s c 51065 d$

www.rsc.org/chemicalscience

\author{
Fabien W. Monnard, ${ }^{a}$ Elisa S. Nogueira, ${ }^{a}$ Tillmann Heinisch, ${ }^{\text {ab }}$ Tilman Schirmer $^{\mathrm{b}}$ \\ and Thomas R. Ward ${ }^{* a}$
}

In the presence of human carbonic anhydrase II, aryl-sulfonamide-bearing IrCp* pianostool complexes catalyze the asymmetric transfer hydrogenation of imines. Critical cofactor-protein interactions revealed by the X-ray structure of $\left[\left(\eta^{5}-C p^{*}\right) \operatorname{Ir}(\right.$ pico 4$\left.) C l\right] 9 \subset$ WT hCA II were genetically optimized to improve the catalytic performance of the artificial metalloenzyme $\left(68 \%\right.$ ee, $\left.k_{\text {cat }} / K_{\mathrm{M}} 6.11 \times 10^{-3} \mathrm{~min}^{-1} \mathrm{mM}^{-1}\right)$.

\section{Introduction}

Artificial metalloenzymes result from the incorporation of an organometallic moiety within a protein scaffold. In this context, three anchoring strategies have been pursued: covalent, supramolecular and dative. ${ }^{1-17}$ In the context of dative anchoring strategies, we hypothesized that human Carbonic Anhydrase II (hCA II hereafter) may provide a suitable scaffold for the creation of artificial metalloenzymes. Indeed, para-substituted aryl-

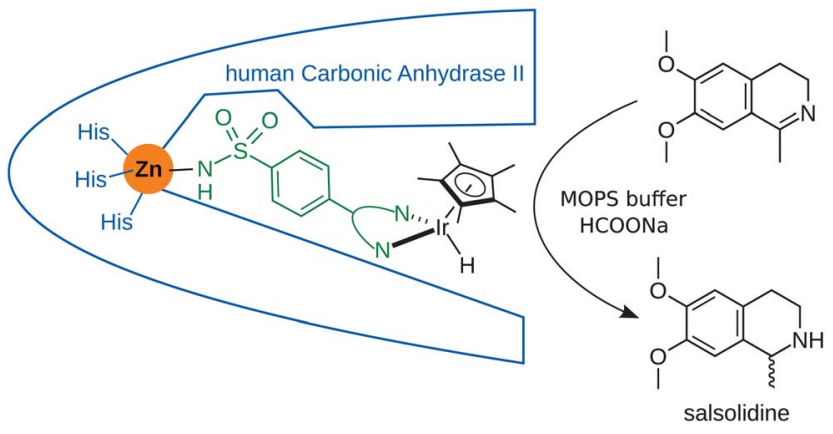

Fig. 1 Artificial transfer hydrogenase for imine reduction. An aryl-sulfonamidebearing bidentate ligand (green) ensures anchoring of an $\operatorname{IrCp} *$-moiety within human carbonic anhydrase II (blue). Variation of the bidentate ligand combined with genetic modification of the host protein allows a chemogenetic optimization of the catalyst's performance for the synthesis of salsolidine.

${ }^{a}$ Department of Chemistry, University of Basel, Spitalstrasse 51, CH-4056 Basel, Switzerland. E-mail: thomas.ward@unibas.ch; Fax: +41 6126710 05; Tel: +41 61 2671004

${ }^{b}$ Biozentrum, University of Basel, Klingelbergstrasse 50/70, CH-4056 Basel, Switzerland. E-mail: tilman.schirmer@unibas.ch; Fax: +41 6126721 09; Tel: +41 612672089

$\dagger$ Electronic supplementary information (ESI) available: Modified protocol for the expression of hCA II in E. Coli. Detailed description of the X-ray structure. Synthesis and characterization of all new compounds. See DOI: $10.1039 / \mathrm{c} 3 \mathrm{sc} 51065 \mathrm{~d}$ sulfonamides display high affinity for the catalytic $\mathrm{Zn}$ ion which lies at the bottom of a deep hydrophobic funnel-shaped cavity. We thus speculated that upon tethering an aryl-sulfonamide to a bidentate ligand may allow to anchor an organometallic catalyst within hCA II. ${ }^{18}$ This was recently confirmed with an X-ray structure of an aryl-sulfonamide-bearing Ru pianostool complex incorporated within hCA II. ${ }^{19,20}$ However, this latter proved catalytically inactive for a variety of transformations. Herein we report on our efforts to create an artificial transfer hydrogenase based on the incorporation of a catalytically active iridium pianostool complex within hCA II, Fig. 1.

\section{Results and discussion}

\subsection{Ligand synthesis}

With the aim of identifying the most suitable scaffold for incorporation within hCA II, we set out to synthesize different ligands bearing a $p$-aryl-sulfonamide anchor. As previously demonstrated, the $\{\mathrm{IrCp} *\}^{2+}$ moiety has proven superior to its $\left\{\mathrm{RhCp}^{*}\right\}^{2+}$ and $\{\mathrm{Ru}(\text { arene })\}^{2+}$ congeners for the reduction of imines in water..$^{21,22}$ The synthesis of bis-pyridine 1, bipyridine 2, amino-pyridine 3 and sulfonamido-pyridine 4 and 5 ligands and the corresponding complexes 6-10 is presented in Schemes 1 and 2 (see ESI $\dagger$ for full experimental details).

The synthesis of bis-pyridine 1 was reported in $2011 .{ }^{19}$ The preparation of bipy 2 started with an aldol condensation reaction between 4-(methylthio)benzaldehyde $\mathbf{1 1}$ and 2-acetylpyridine 12, to afford the corresponding phenyl-substitutedbipyridine 13. ${ }^{23}$ The sulfonamide anchor was installed in three steps via oxidation of the thiomethyl function, ${ }^{24}$ which was converted to the sulfonamide using the method disclosed by Zhang et al. ${ }^{25}$ The sulfonamide-bearing bipyridine ligand 2 was obtained in $8 \%$ overall yield, Scheme 1.

The synthesis of 2-picolylamine-bearing ligand 3 relied on a palladium-catalyzed cross-coupling strategy as key step. Commercially available chloropyridine $\mathbf{1 4}$ and aryl-sulfonamide 

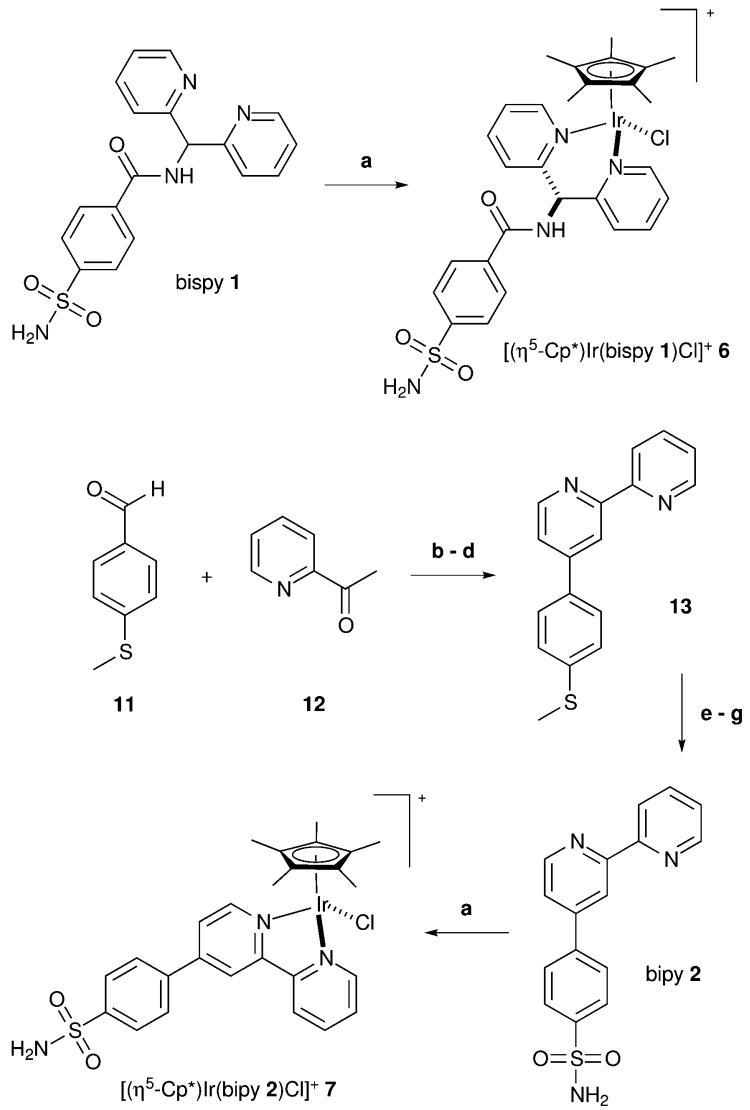

Scheme 1 Synthesis of pianostool complexes $\mathbf{6}$ and $\mathbf{7}$ bearing bis-pyridine-type bidentate ligands. Reagents and conditions: (a) $\left.\left[\mathrm{Cp}^{*} \mid \mathrm{rCl}\right]_{2}\right]_{2}, \mathrm{H}_{3} \mathrm{CCN}$, reflux, $4 \mathrm{~h}$; (b) $\mathrm{NaOH}$ aq./MeOH, RT; (c) ethyl vinyl ether, $4 \AA$ molecular sieves, THF, RT; (d) $\mathrm{H}_{2} \mathrm{NO} \cdot \mathrm{HCl}, \mathrm{H}_{3} \mathrm{CCN}$, reflux; (e) $\mathrm{KMnO}_{4} / \mathrm{MnO}_{2}, \mathrm{CH}_{2} \mathrm{Cl}_{2}, \mathrm{RT}$; (f) (i) DIPA, $n$-BuLi, THF, $0{ }^{\circ} \mathrm{C}$, (ii) trimethylsilyl chloride, $\mathrm{RT}$; (g) (i) TBAF, THF, reflux, (ii) hydroxylamine-Osulfonic acid, $\mathrm{H}_{2} \mathrm{O}$, RT.

15 were coupled under Suzuki conditions. Reduction of the nitrile with $\left(\mathrm{AlCl}_{3}\right) \cdot \mathrm{LiAlH}_{4}$, followed by deprotection with TFA afforded the corresponding ligand 3 in $40 \%$ overall yield. ${ }^{26,27}$

For the synthesis of ligands pico $4-\mathrm{H}$ and pico $5-\mathrm{H}$, the oxime 17 was identified as advanced intermediate, easily accessed on large scale from commercially available 4-bromo-2methylpyridine 16. Its synthesis was based on key steps starting from a Boekelheide reaction ${ }^{28,29}$ and followed by an oxidation to the corresponding aldehyde. ${ }^{30}$ Treatment with hydroxylamine hydrochloride yielded the oxime 17 . Reduction by $\mathrm{Zn}$ in trifluoroacetic acid ${ }^{31}$ followed by treatment with an aryl-sulfonylchloride derivative yielded the sulfonamide-pyridines 18 and 19, respectively. ${ }^{32}$ Finally, the benzene sulfonamide anchor was introduced via Suzuki cross-coupling reaction to afford the bidentate ligands pico $4-\mathrm{H}$ and pico $5-\mathrm{H}$ in $5 \%$ overall yield. ${ }^{33}$

The aminosulfonamide-bearing ligands 1-5 were reacted with $\left[\mathrm{Cp}^{*} \mathrm{IrCl}_{2}\right]_{2}$ to afford the corresponding mononuclear pianostool complexes $\left[\left(\eta^{5}-\mathrm{Cp}{ }^{*}\right) \operatorname{Ir}(\text { bispy 1)Cl }]^{+} \mathbf{6},\left[\left(\eta^{5}-\mathrm{Cp} \mathrm{p}^{*}\right) \operatorname{Ir}(\right.\right.$ bipy 2$)-$ $\mathrm{Cl}]^{+} 7$ and $\left[\left(\eta^{5}-\mathrm{Cp} *\right) \operatorname{Ir}(\text { pico } 3) \mathrm{Cl}\right]^{+} \mathbf{8},\left[\left(\eta^{5}-\mathrm{Cp} *\right) \operatorname{Ir}(\right.$ pico 4$\left.) \mathrm{Cl}\right] \mathbf{9}$ and $\left[\left(\eta^{5}-\mathrm{Cp} *\right) \operatorname{Ir}(\right.$ pico 5)Cl] 10 respectively. These were purified by precipitation in acetonitrile or $\mathrm{CH}_{2} \mathrm{Cl}_{2}$ to afford analytically pure aryl-sulfonamide-bearing iridium pianostool complexes for anchoring within hCA II, Schemes 1 and 2.

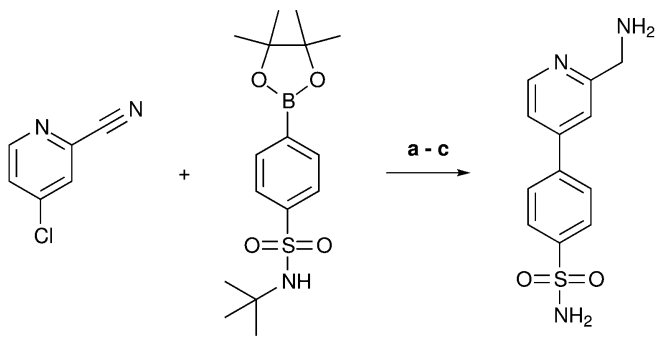

14

15 pico 3

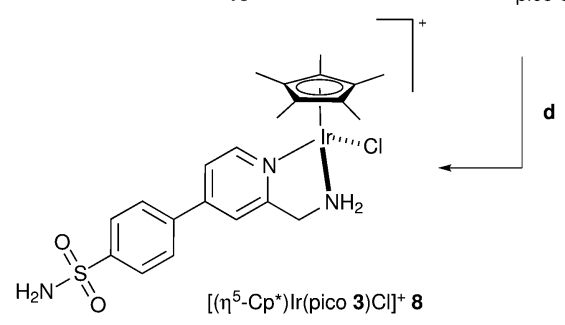<smiles>[X]c1cccc([X])c1S(=O)(=O)NCc1cc(Br)ccn1</smiles>

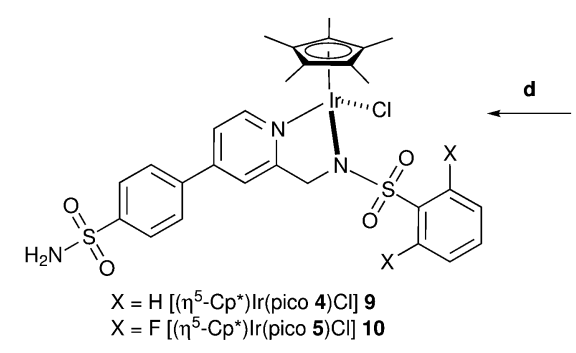<smiles>[X]c1cccc([X])c1S(=O)(=O)NCc1cc(-c2ccc(S(N)(=O)=O)cc2)ccn1</smiles>

Scheme 2 Synthesis of pianostool complexes 8-10 bearing picolylamine-type bidentate ligands. Reagents and conditions: (a) $\mathrm{Pd}\left(\mathrm{PPh}_{3}\right)_{4}, \mathrm{Na}_{2} \mathrm{CO}_{3}, \mathrm{THF}, 80{ }^{\circ} \mathrm{C}$; (b) $\mathrm{LiAlH}_{4} \cdot \mathrm{AlCl}_{3}$, THF, RT; (c) TFA, RT; (d) $\left[\mathrm{Cp} * \mathrm{IrCl}_{2}\right]_{2}$, EtOH, reflux; (e) $m$-CPBA, $\mathrm{CH}_{2} \mathrm{Cl}_{2}$, RT; (f) TFAA, $\mathrm{CH}_{2} \mathrm{Cl}_{2}, 0^{\circ} \mathrm{C}$; (g) $\mathrm{MnO}_{2}, \mathrm{CH}_{3} \mathrm{Cl}$, reflux; (h) $\mathrm{H}_{2} \mathrm{NO} \cdot \mathrm{HCl}, \mathrm{NaHCO}_{3}, \mathrm{MeOH}$, $\mathrm{RT}$; (i) TFA, $\mathrm{Zn}, 0^{\circ} \mathrm{C}$; (j) arylsulfonylchloride, DIPEA, RT; (k) Pd(PPh $)_{4}, \mathrm{Na}_{2} \mathrm{CO}_{3}, \mathrm{H}_{2} \mathrm{O}$ / dioxane, microwave, $150{ }^{\circ} \mathrm{C}$.

\subsection{Catalysis results}

In order to evaluate the transfer hydrogenase activity of the pianostool complexes 6-10, the salsolidine precursor was selected as prochiral imine. ${ }^{34}$ The sulfonamide-bearing catalysts 6-10 (1.8 mol\% vs. imine, 5\% DMSO in MOPS buffer, pH 7.5, $40{ }^{\circ} \mathrm{C}, 20$ hours, 150 eq. $\mathrm{HCO}_{2} \mathrm{Na}$ ) were tested both in the absence and in the presence of hCA II (see ESI $\dagger$ for experimental details). From these data, it appears that both bispy- and bipybearing complexes $\left[\left(\eta^{5}-\mathrm{Cp} *\right) \operatorname{Ir}(\text { bispy } 1) \mathrm{Cl}\right]^{+} \mathbf{6}$ and $\left[\left(\eta^{5}-\mathrm{Cp}^{*}\right)\right.$ $\operatorname{Ir}($ bipy 2$) \mathrm{Cl}]^{+} 7$ are very poor transfer hydrogenation catalysts (Table 1, entries 1-4). In contrast, the complex bearing the 
Table 1 Selected results for the chemogenetic optimization of artificial transfer hydrogenases for the production of salsolidine ${ }^{a}$ at $40{ }^{\circ} \mathrm{C}$

\begin{tabular}{lllll}
\hline Entry & Complex & hCA II & Conv. \% & ee \% \\
\hline 1 & $\mathbf{6}$ & - & 3 & n.d. \\
2 & $\mathbf{6}$ & WT & 0 & n.d. \\
3 & 7 & - & 14 & n.d. \\
4 & 7 & WT & 0 & n.d. \\
5 & $\mathbf{8}$ & - & Quant. & Rac. \\
6 & $\mathbf{8}$ & WT & 20 & $5(S)$ \\
7 & $\mathbf{8}$ & I91A & 46 & $1(S)$ \\
8 & $\mathbf{8}$ & K170A & 34 & $3(S)$ \\
9 & $\mathbf{9}$ & - & 81 & $1(S)$ \\
10 & $\mathbf{9}$ & WT & 69 & $32(S)$ \\
11 & $\mathbf{9}$ & I91A & 67 & $29(S)$ \\
12 & $\mathbf{9}$ & K170A & 40 & $30(S)$ \\
13 & $\mathbf{1 0}$ & - & 86 & $2(R)$ \\
14 & $\mathbf{1 0}$ & WT & 51 & $30(S)$ \\
15 & $\mathbf{1 0}$ & I91A & 58 & $5(R)$ \\
16 & $\mathbf{1 0}$ & K170A & 25 & $14(S)$
\end{tabular}

${ }^{a}$ The reaction was carried out for $20 \mathrm{~h}$ at $40{ }^{\circ} \mathrm{C}$ with $0.35 \mathrm{mM}$ complex (final concentration, $1.8 \mathrm{~mol} \%$ vs. substrate), $0.4 \mathrm{mM}$ hCA II in MOPS buffer $(0.4 \mathrm{M}, \mathrm{pH} 7.5,200 \mu \mathrm{L}$ containing 5\% DMSO), $20 \mathrm{mM}$ imine substrate and $3 \mathrm{M}$ formate. The yield and ee is an average of at least two catalytic runs $\delta$ ee: $\pm 1 \%, \delta$ conv.: $\pm 4 \%$.

amino-pyridine ligand $\left[\left(\eta^{5}-\mathrm{Cp} *\right) \operatorname{Ir}(\text { pico } 3) \mathrm{Cl}\right]^{+} 8$ performed well in the absence of hCA II ( $>55$ turnover numbers, TON). Disappointingly, incorporation within hCA II lead to a significant erosion of its catalytic performance (TON 11, ee $5 \%(S)$, Table 1 , entries 5 and 6). A recent report by Çetinkaya suggests that the transfer hydrogenase activity of $\mathrm{d}^{6}$-pianostool complexes with a sulfonamide-bearing 2-picolylamine is superior to that of the corresponding the 2-picolylamine-containing catalyst. ${ }^{35} \mathrm{We}$ thus set out to synthesize and evaluate the activity of $\left[\left(\eta^{5}-\mathrm{Cp}^{*}\right)\right.$ $\operatorname{Ir}\left(\right.$ pico 4)Cl] 9. Although less active than $\left[\left(\eta^{5}-\mathrm{Cp} *\right) \operatorname{Ir}(\text { pico 3 }) \mathrm{Cl}\right]^{+} \mathbf{8}$ in the absence of host protein (45 vs. $>55$ TONs), incorporation within hCA II yielded salsolidine in $69 \%$ yield and $32 \%$ ee $(S)$ (Table 1, entries 9 and 10). Inspired by Carreira's observation that fluorination of the aryl-moiety of amino-sulfonamide ligands leads to improved transfer hydrogenase activity in water, we tested the difluorinated catalyst $\left[\left(\eta^{5}-\mathrm{Cp} *\right) \operatorname{Ir}(\right.$ pico 5$\left.) \mathrm{Cl}\right]$ $10 .^{36}$ Unfortunately, its catalytic performance remained modest both in the absence and within hCA II (Table 1, entries 13-16). These results highlight the critical influence of the second coordination sphere interactions on the catalytic performance of pianostool complexes with a well defined first coordination sphere.

With the aim of identifying critical residues in the most promising ATHase based on WT hCA II, the X-ray structure of $\left[\left(\eta^{5}-\mathrm{Cp}{ }^{*}\right) \operatorname{Ir}(\right.$ pico 4$\left.) \mathrm{Cl}\right] \mathbf{9} \subset$ hCA II was determined (vide infra, see Fig. 3). The structure revealed the proximity of residues I91 and K170 to the artificial cofactor, lining the hemisphere potentially occupied by the substrate. With the aim of tailoring more space for the substrate binding pocket, hCA II single mutants I91A and K170A were produced, purified and tested as host protein (see $\mathrm{ESI} \dagger$ for details).

As for WT hCA II, both ATHase mutants $\left[\left(\eta^{5}-\mathrm{Cp}^{*}\right) \operatorname{Ir}(\right.$ pico 4)$\mathrm{Cl}] \mathbf{9} \subset \mathrm{I} 91 \mathrm{~A}$ and $\left[\left(\eta^{5}-\mathrm{Cp} *\right) \operatorname{Ir}(\right.$ pico 4) Cl $] \mathbf{9} \subset$ K170A displayed good TONs and similar ees at $40{ }^{\circ} \mathrm{C}$ (Table 1, entries 11 and 12). Upon decreasing the temperature to $4{ }^{\circ} \mathrm{C}$, the bare catalyst $\left[\left(\eta^{5}\right.\right.$ $\left.\mathrm{Cp}^{*}\right) \operatorname{Ir}($ pico 4)Cl] 9 showed low ATHase activity (Table 2, entry 5). In contrast, both $\left[\left(\eta^{5}-\mathrm{Cp} \mathrm{p}^{*}\right) \operatorname{Ir}(\right.$ pico 4)Cl $] \mathbf{9} \subset$ WT hCA II and $\left[\left(\eta^{5}-\right.\right.$ Cp*)Ir(pico 4)Cl] $9 \subset$ I91A afforded salsolidine with significantly improved selectivity at $4{ }^{\circ} \mathrm{C}(68 \%$ ee $(S), 27 \%$ conv. and $64 \%$ ee $(S), 23 \%$ conv. respectively). Upon increasing the catalyst loading to $9 \%$, the conversions could be upgraded to $82 \%$ and $70 \%$ respectively after 44 hours (Table 2, entries 9 and 10).

\subsection{Kinetic- and thermodynamic characterization}

Para-substituted aryl-sulfonamides are widely studied inhibitors for hCA II and their affinities vary over several orders of magnitude. ${ }^{18}$ In order to ensure that, under catalytic conditions (i.e. $[\mathrm{hCA} \mathrm{II}]=0.4 \mathrm{mM}$; [complex] $=0.35 \mathrm{mM}$ ), the bulky pianostool complexes were quantitatively incorporated within hCA II, their affinity towards hCA II was determined (see ESI $\dagger$ for details). ${ }^{19,37-41}$ It is interesting to note that the sulfonamidebearing pianostool complexes $\left[\left(\eta^{5}-\mathrm{Cp} *\right) \operatorname{Ir}(\right.$ pico 4$\left.) \mathrm{Cl}\right] \mathbf{9}$ and $\left[\left(\eta^{5}-\right.\right.$ $\left.\mathrm{Cp}^{*}\right) \operatorname{Ir}($ pico 5)Cl] 10 displayed significantly higher affinity towards hCA II compared to the picolylamine complex $\left[\left(\eta^{5}-\mathrm{Cp} *\right)\right.$ $\mathrm{Ir}(\text { pico 3)Cl] }]^{+} \mathbf{8}$ (compare $15 \mathrm{nM}$ and $17 \mathrm{nM}$ for complexes 9 and 10 respectively to $1280 \mathrm{nM}$ for complex 8, Table 3, entries 3-5). This suggests that a secondary hydrophobic contact between the additional aryl group of the ligand and the hydrophobic funnel-shaped hCA II active site contributes to significantly increase the affinity of these complexes. ${ }^{42}$

Having ensured that the pianostool complexes are indeed quantitatively incorporated within hCA II under catalytic conditions, the saturation kinetics behavior of $\left[\left(\eta^{5}-\mathrm{Cp} \mathrm{p}^{*}\right) \operatorname{Ir}(\mathrm{pico}\right.$ 4)Cl $]$ 9, $\left[\left(\eta^{5}-\mathrm{Cp} *\right) \operatorname{Ir}(\right.$ pico 4)Cl $] 9 \subset$ WT hCA II and $\left[\left(\eta^{5}-\mathrm{Cp}{ }^{*}\right)\right.$ $\operatorname{Ir}($ pico 4)Cl] $9 \subset$ I91A hCA II was determined, Fig. 2. Upon

Table 2 Selected results for the chemogenetic optimization of artificial transfer hydrogenases for the production of salsolidine ${ }^{a}$ at $4{ }^{\circ} \mathrm{C}$

\begin{tabular}{lllrl}
\hline Entry & Complex & hCA II & Conv. \% & ee \% \\
\hline 1 & $\mathbf{8}$ & & 78 & Rac. \\
2 & $\mathbf{8}$ & WT & 7 & $9(S)$ \\
3 & $\mathbf{8}$ & I91A & 9 & $2(R)$ \\
4 & $\mathbf{8}$ & K170A & 8 & $3(R)$ \\
5 & $\mathbf{9}$ & - & 7 & Rac. \\
6 & $\mathbf{9}$ & WT & 27 & $68(S)$ \\
7 & $\mathbf{9}$ & I91A & 23 & $64(S)$ \\
8 & $\mathbf{9}$ & K170A & 21 & $67(S)$ \\
9 & $\mathbf{9}$ & WT & 82 & $70(S)$ \\
10 & $\mathbf{9}^{b}$ & I91A & 70 & $66(S)$ \\
11 & $\mathbf{9}^{b}$ & K170A & 57 & $68(S)$ \\
12 & $\mathbf{1 0}$ & - & 10 & $2(R)$ \\
13 & $\mathbf{1 0}$ & WT & 7 & $40(S)$ \\
14 & $\mathbf{1 0}$ & I91A & 9 & $15(S)$ \\
15 & $\mathbf{1 0}$ & K170A & 6 & $16(S)$
\end{tabular}

${ }^{a}$ Reactions were carried out for $44 \mathrm{~h}$ at $4{ }^{\circ} \mathrm{C}$ with $0.35 \mathrm{mM}$ complex (final concentration), $20 \mathrm{mM}$ substrate, $0.4 \mathrm{mM}$ protein, MOPS buffer $(0.4 \mathrm{M}$, $\mathrm{pH} 7.5,200 \mu \mathrm{L}, 5 \% \mathrm{DMSO})$ and $3 \mathrm{M}$ formate. ${ }^{b}$ Reactions were carried out for $44 \mathrm{~h}$ at $4{ }^{\circ} \mathrm{C}$ with $0.35 \mathrm{mM}$ complex (final concentration), 4 $\mathrm{mM}$ substrate, $0.4 \mathrm{mM}$ protein, MOPS buffer $(0.4 \mathrm{M}, \mathrm{pH} 7.5,200 \mu \mathrm{L}$, $5 \% \mathrm{DMSO}$ ) and $3 \mathrm{M}$ formate. The yield and ee is an average of at least two catalytic runs $\delta$ ee: $\pm 2 \%, \delta$ conv.: $\pm 5 \%$. 
Table 3 Summary of affinity constants for sulfonamide-bearing pianostool complexes 6-10 towards WT hCA II

\begin{tabular}{llc}
\hline Entry & Complex & $K_{\mathrm{d}} / \mathrm{nM}$ \\
\hline 1 & $\mathbf{6}^{a}$ & $120 \pm 20$ \\
2 & $7^{a}$ & $270 \pm 40$ \\
3 & $\mathbf{8}^{a}$ & $1280 \pm 200$ \\
4 & $\mathbf{9}^{b}$ & $15 \pm 2$ \\
5 & $\mathbf{1 0}^{a}$ & $17 \pm 8$
\end{tabular}

${ }^{a}$ Affinity determined using the rate of hydrolysis of $p$ nitrophenylacetate. ${ }^{b}$ Affinity determined using competition with dansylamide (see ESI for experimental details).

varying the imine concentration and determining by HPLC the initial rate of salsolidine formation, very different kinetic profiles were obtained, Fig. 2 . For the bare catalyst $\left[\left(\eta^{5}-\mathrm{Cp} *\right)\right.$ $\operatorname{Ir}($ pico 4) $\mathrm{Cl}]$ 9, the reaction rate was essentially independent of the imine concentration at [imine] $>1.17 \mathrm{mM}$. Unfortunately, lowering the imine concentration below $1.17 \mathrm{mM}$ (i.e. less than three eq. vs. $\left[\left(\eta^{5}-\mathrm{Cp} *\right) \operatorname{Ir}(\right.$ pico 4)Cl] 9) renders the pseudo first order kinetics approximation invalid and thus precludes the precise determination of $k_{\text {cat }}$ for the reaction in the absence of hCA II. Two possibilities may be put forward to explain the behaviour of the free cofactor $\left[\left(\eta^{5}-\mathrm{Cp}{ }^{*}\right) \operatorname{Ir}\left(\right.\right.$ pico 4) Cl] 9: (i) $K_{\mathrm{M}}<$ $1.17 \mathrm{mM}$ or (ii) the substrate is not involved in the rate determining step.

In stark contrast, upon incorporation within hCA II isoforms, saturation kinetic profiles were observed. For $\left[\left(\eta^{5}-\mathrm{Cp}^{*}\right)\right.$ Ir(pico 4)Cl] $9 \subset$ WT hCA II, severe substrate inhibition was observed $\left(K_{\mathrm{i}} 45 \mathrm{mM}\right)$. A single point mutation with $\left[\left(\eta^{5}-\mathrm{Cp} *\right)\right.$ $\operatorname{Ir}($ pico 4)Cl] $9 \subset$ I91A hCA II removed the substrate inhibition. $\left(k_{\text {cat }} / K_{\mathrm{M}}: 9.9 \times 10^{-3} \mathrm{~min}^{-1} \mathrm{mM}^{-1}\right.$ vs. $6.1 \times 10^{-3} \mathrm{~min}^{-1} \mathrm{mM}^{-1}$ for $\left[\left(\eta^{5}-\mathrm{Cp}^{*}\right) \operatorname{Ir}(\right.$ pico 4)Cl $] 9 \subset$ WT hCA II and $\left[\left(\eta^{5}-\mathrm{Cp} *\right) \operatorname{Ir}(\right.$ pico 4)Cl] $9 \subset$ I91A hCA II, respectively, Fig. 2.) Comparing the saturation kinetics behavior of the artificial metalloenzyme with that of the organometallic catalyst demonstrates that the host

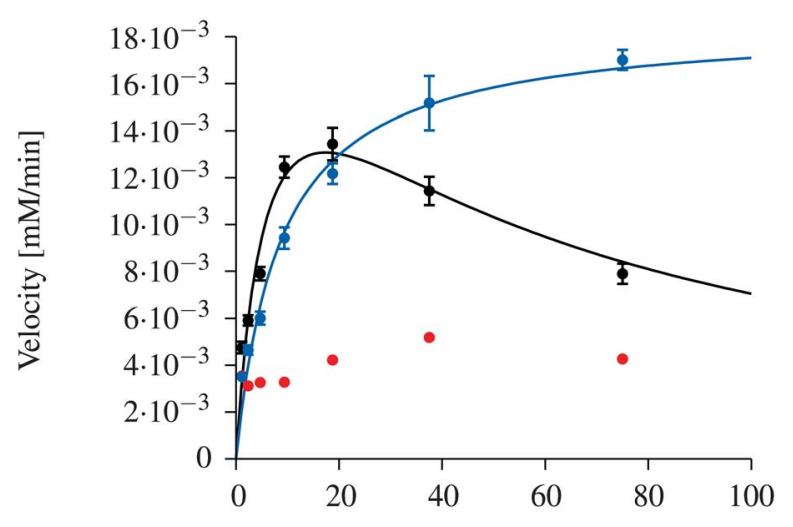

Substrate concentration $[\mathrm{mM}]$

Fig. 2 Kinetic profiles of $\left[\left(\eta^{5}-C p^{*}\right) \operatorname{Ir}(\text { pico } 4) C l\right]^{+} \mathbf{9}\left(\right.$ red), $\left[\left(\eta^{5}-C p^{*}\right) \operatorname{Ir}(\text { pico } 4) C l\right]^{+} \mathbf{9}$ $\subset$ WT hCA II (black trace: $K_{\mathrm{M}} 6.67 \pm 2.20 \mathrm{mM}, K_{\mathrm{i}} 45 \pm 15 \mathrm{mM}, k_{\text {cat }} 6.60 \times 10^{-2} \pm$ $\left.1.17 \times 10^{-2} \mathrm{~min}^{-1}\right)$ and $\left[\left(\eta^{5}-\mathrm{Cp} *\right) \operatorname{Ir}(\text { pico } 4) \mathrm{Cl}\right]^{+} \mathbf{9} \subset 191 \mathrm{~A}$ hCA II (blue trace: $K_{\mathrm{M}}$ $8.63 \pm 1.30 \mathrm{mM}, k_{\text {cat }} 5.28 \times 10^{-2} \pm 0.23 \times 10^{-2} \mathrm{~min}^{-1}$ ). protein has a major impact on the respective kinetic profiles of the three catalysts.

\subsection{X-ray structure of the hCA II metalloenzyme}

To gain structural insight on the ATHase $\left[\left(\eta^{5}-\mathrm{Cp}^{*}\right) \operatorname{Ir}(\right.$ pico 4 $\left.) \mathrm{Cl}\right] \mathbf{9}$ $\subset$ hCA II, diffraction data were collected to $1.3 \AA$ resolution of a hCA II crystal after soaking in a solution of complex 9. Upon solving the crystal structure, residual density was apparent in the funnel-shaped active site of hCA II in close proximity to the catalytic zinc (Fig. 3). The pyridine and terminal benzenesulfonamide moieties of complex 9 were modeled into the density with the sulfonamide forming a coordinative bond with the catalytic zinc and the benzene and pyridine ring arranged virtually coplanarly. A strong peak in both the $F_{\mathrm{o}}-F_{\mathrm{c}}$ and the anomalous difference density map ( $23 \sigma$ and $8 \sigma$, respectively) indicated the presence of the Ir atom in close proximity to the pyridine. The atom, however, is not fully occupied as found upon refinement, which yielded $30 \%$ occupancy. The low occupancy may be due to partial dissociation of the metal upon complex binding to the protein. The iridium is coordinated by the pyridine nitrogen and the nitrogen of the secondary benzenesulfonamide. Consistent with the low occupancy, no electron density was observed for the $\mathrm{Cp}^{*}$ ring, the chlorine, and the secondary benzenesulfonamide. In the final model of the fully coordinated Ir atom the occupancy of these groups was set to $30 \%$. Upon refinement no negative density emerged in the $F_{\mathrm{o}}-F_{\mathrm{c}}$ map. The pianostool moiety of the complex 9 is located in an hydrophobic groove formed by residues F131, V135, L198, P202 and L204.

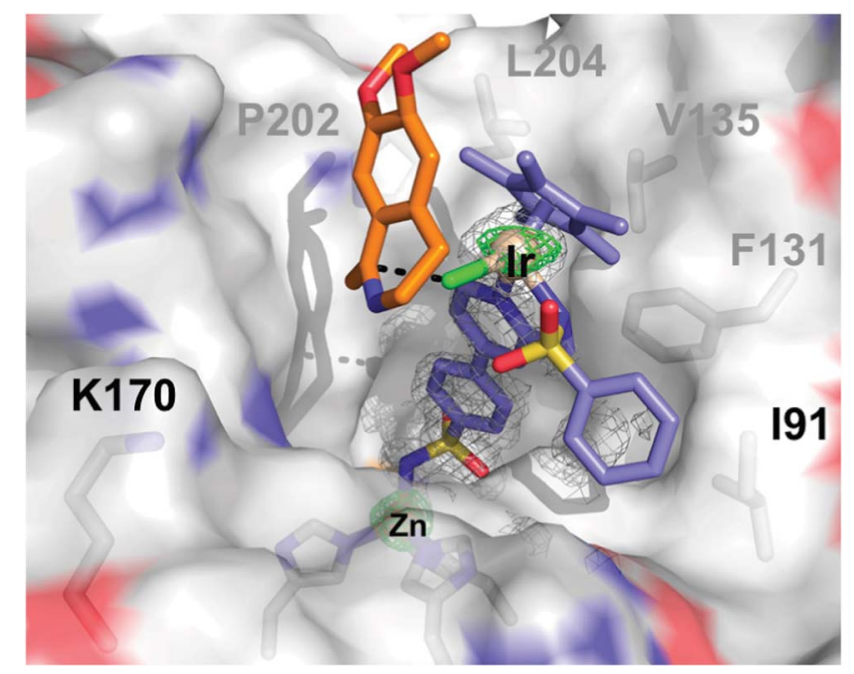

Fig. 3 Close-up view of the active site in the crystal structure of complex $\mathbf{9} \subset$ hCA II (PDB code 3ZP9). Complex $\mathbf{9}$ is depicted in stick representation. The protein is represented in surface representation with oxygens and nitrogens in red and blue color, respectively. Residues of the hydrophobic wall (P131, V135, P202, L204) and those that were chosen for genetic optimization (191, K170) are highlighted through the surface as stick representation. The occupancies of the $\{|r C p * C|\}^{+}$fragment and the secondary benzenesulfonamide in the eclipsedconformation are $30 \%$. The salsolidine precursor (orange) was qualitatively modeled in the active site to yield the observed (S)-enantiomer of the product. The electron density of the $F_{\mathrm{o}}-F_{\mathrm{c}}$ omit map (grey color) and the anomalous difference density (green color) are contoured at $3 \sigma$ and $4 \sigma$, respectively. 
Residual density in the $F_{\mathrm{o}}-F_{\mathrm{c}}$ omit map was encountered in proximity to the secondary benzenesulfonamide. Rotation of this group around the $\mathrm{N}_{\mathrm{py}}-\mathrm{C}-\mathrm{C}-\mathrm{N}$ bond by $135^{\circ}$ positions the sulfur atom in this density. Thus, upon dissociation of the iridium, the secondary benzenesulfonamide may undergo a conformational change from an eclipsed- to an anticlinalconformation. This would account for up to $70 \%$ of the total occupancy of the ligand (ESI Fig. S6 $\dagger$ ). In both, the eclipsed-and the anticlinal-conformation, the aromatic ring of the secondary benzenesulfonamide group is located in proximity to the side chains of E69, D72, I91 and F131.

A qualitative model of the ATHase $9 \subset$ hCA II in complex with the salsolidine precursor was constructed based on the structural and the functional data (Fig. 3). The substrate binding site is constituted by complex 9 and residues H4, L60, N62, H64, K170 and G171, which, thus, are target amino acids for future genetic optimization of the ATHase (ESI Fig. S7 $\dagger$ ).

It is conceivable that the reduction of the side-chain-size in the I91A mutant changes the relative position of the substrate to the cofactor. However, it is not obvious from the X-ray structure how this abrogates the observed substrate inhibition.

\section{Outlook}

With the aim of creating artificial transfer hydrogenases based on hCA II as protein scaffold, five IrCp*-complexes bearing $\mathrm{N}^{\wedge} \mathrm{N}$ bidentate ligands were screened. While the bare catalyst proved only moderately active, upon incorporation in hCA II, complex $\left[\left(\eta^{5}-\mathrm{Cp}^{*}\right) \operatorname{Ir}(\right.$ pico 4$\left.) \mathrm{Cl}\right] \mathbf{9}$ displayed significantly improved catalytic performance both in terms of activity and selectivity at $4{ }^{\circ} \mathrm{C}$ (up to $68 \%$ ee). Saturation kinetic analysis of the WT ATHase revealed however severe substrate inhibition. Guided by the Xray structure of complex $\left[\left(\eta^{5}-\mathrm{Cp} *\right) \operatorname{Ir}(\right.$ pico 4$\left.) \mathrm{Cl}\right] \mathbf{9} \subset$ WT hCA II, the catalytic site was expanded by mutation of close-lying isoleucine 91 into an alanine. This chemogenetically optimized ATHase $\left[\left(\eta^{5}-\mathrm{Cp}^{*}\right) \operatorname{Ir}(\right.$ pico 4$\left.) \mathrm{Cl}\right] \mathbf{9} \subset$ I91A hCA II no longer suffered from substrate inhibition and displayed significant rate enhancement over the organometallic catalyst. Current efforts are aimed at further engineering the catalytic site by genetic introduction of additional substrate recognition elements.

\section{Acknowledgements}

FWM thanks the Novartis Foundation and the Swiss Nanoscience Institute for financial support. EN thanks Marie Curie ITN (Biotrains FP7-ITN-238531). TH thanks the Marie Curie ITN (BioChemLig FP7-ITN-238434) TRW thanks C. Fierke for the hCA II plasmid and Umicore for a loan of Ir.

\section{References}

1 D. Qi, C.-M. Tann, D. Haring and M. D. Distefano, Chem. Rev., 2001, 101, 3081.

2 T. R. Ward, Acc. Chem. Res., 2011, 44, 47.

3 F. Rosati and G. Roelfes, ChemCatChem, 2010, 2, 916.
4 P. J. Deuss, R. denHeeten, W. Laan and P. C. J. Kamer, Chem.-Eur. J., 2011, 17, 4680.

5 M. T. Reetz, Top. Organomet. Chem., 2009, 25, 63.

6 S. Abe, T. Ueno and Y. Watanabe, Top. Organomet. Chem., 2009, 25, 25.

7 J. Steinreiber and T. R. Ward, Coord. Chem. Rev., 2008, 252, 751.

8 D. K. Garner, L. Liang, D. A. Barrios, J.-L. Zhang and Y. Lu, ACS Catal., 2011, 1, 1083.

9 Q. Jing, K. Okrasa and R. J. Kazlauskas, Chem.-Eur. J., 2009, $15,1370$.

10 M. Ohashi, T. Koshiyama, T. Ueno, M. Yanase, H. Fujii and Y. Watanabe, Angew. Chem., Int. Ed., 2003, 42, 1005.

11 C. Mayer, D. G. Gillingham, T. R. Ward and D. Hilvert, Chem. Commun., 2011, 47, 12068.

12 T. Matsuo, C. Imai, T. Yoshida, T. Saito, T. Hayashi and S. Hirota, Chem. Commun., 2012, 48, 1662.

13 C. Esmieu, M. V. Cherrier, P. Amara, E. Girgenti, C. MarchiDelapierre, F. Oddon, M. Iannello, A. Jorge-Robin, C. Cavazza and S. Ménage, Angew. Chem., Int. Ed., 2013, 52, 3922.

14 J. Bos, F. Fusetti, A. J. M. Driessen and G. Roelfes, Angew. Chem., Int. Ed., 2012, 51, 7472.

15 Y. Lu, N. Yeung, N. Sieracki and N. M. Marshall, Nature, 2009, 460, 855.

16 A. Fernández-Gacio, A. Codina, J. Fastrez, O. Riant and P. Soumillion, ChemBioChem, 2006, 7, 1013.

17 Q. Jing and R. J. Kazlauskas, ChemCatChem, 2010, 2, 953.

18 V. M. Krishnamurthy, G. K. Kaufman, A. R. Urbach, I. Gitlin, K. L. Gudiksen, D. B. Weibel and G. M. Whitesides, Chem. Rev., 2008, 108, 946.

19 F. W. Monnard, T. Heinisch, E. S. Nogueira, T. Schirmer and T. R. Ward, Chem. Commun., 2011, 47, 8238.

20 D. Can, B. Spingler, P. Schmutz, F. Mendes, P. Raposinho, C. Fernandes, F. Carta, A. Innocenti, I. Santos, T. C. Supuran and R. Alberto, Angew. Chem., Int. Ed., 2012, $\mathbf{5 1}, 3354$.

21 M. Dürrenberger, T. Heinisch, Y. Wilson, T. Rossel, E. Nogueira, L. Knörr, A. Mutschler, K. Kersten, M. Zimbron, J. Pierron, T. Schirmer and T. R. Ward, Angew. Chem., Int. Ed., 2011, 50, 3026.

22 C. Wang, B. Villa-Marcos and J. Xiao, Chem. Commun., 2011, 47, 9773.

23 J. G. Cordaro, J. K. McCusker and R. G. Bergman, Chem. Commun., 2002, 1496.

24 A. Shaabani, P. Mirzaei, S. Naderi and D. G. Lee, Tetrahedron, 2004, 60, 11415.

25 I. K. Khanna, Y. Yu, R. M. Huff, R. M. Weier, X. Xu, F. J. Koszyk, P. W. Collins, J. N. Cogburn, P. C. Isakson, C. M. Koboldt, J. L. Masferrer, W. E. Perkins, K. Seibert, A. W. Veenhuizen, J. Yuan, D. C. Yang and Y. Y. Zhang, J. Med. Chem., 2000, 43, 3168.

26 W. F. McCalmont, J. R. Patterson, M. A. Lindenmuth, T. N. Heady, D. M. Haverstick, L. S. Gray and T. L. Macdonald, Bioorg. Med. Chem., 2005, 13, 3821.

27 B. L. Bourdonnec, E. Meulon, S. Yous, J. F. Goossens, R. Houssin and J. P. Henichart, J. Med. Chem., 2000, 43, 2685. 
28 R. C. Jones, A. J. Canty, J. A. Deverell, M. G. Gardiner, R. M. Guijt, T. Rodemann, J. A. Smith and V. A. Tolhurst, Tetrahedron, 2009, 65, 7474.

29 M. van den Heuvel, T. A. van den Berg, R. M. Kellogg, C. T. Choma and B. L. Feringa, J. Org. Chem., 2004, 69, 250.

30 Y. Ishida, M. Inoue, T. Inoue, A. Ojida and I. Hamachi, Chem. Commun., 2009, 2848.

31 S. Negi, M. Matsukura, M. Mizuno, K. Miyake and N. Minami, Synthesis, 1996, 991.

32 M. Penso, D. Albanese, D. Landini, V. Lupi and A. Tagliabue, J. Org. Chem., 2008, 73, 6686.

33 J. A. Christopher, P. Bamborough, C. Alder, A. Campbell, G. J. Cutler, K. Down, A. M. Hamadi, A. M. Jolly, J. K. Kerns, F. S. Lucas, G. W. Mellor, D. D. Miller, M. A. Morse, K. D. Pancholi, W. Rumsey, Y. E. Solanke and R. Williamson, J. Med. Chem., 2009, 52, 3098.
34 T. S. Kaufman, Tetrahedron: Asymmetry, 2004, 15, 1203.

35 S. Günnaz, N. Özdemir, S. Dayan, O. Dayan and B. Çetinkaya, Organometallics, 2011, 30, 4165.

36 O. Soltani, M. A. Ariger, H. Vázquez-Villa and E. M. Carreira, Org. Lett., 2010, 12, 2893.

37 L. Qin and D. K. Srivastava, Biochemistry, 1998, 37, 3499.

38 M. Schmid, E. S. Nogueira, F. W. Monnard, T. R. Ward and M. Meuwly, Chem. Sci., 2012, 3, 690.

39 R. Iyer, A. A. Barrese III, S. Parakh, C. N. Parker and B. C. Tripp, J. Biomol. Screening, 2006, 11, 782.

40 T. T. Baird Jr, A. Waheed, T. Okuyama, W. S. Sly and C. A. Fierke, Biochemistry, 1997, 36, 2669.

41 S. C. Wang and D. B. Zamble, Biochem. Mol. Biol. Educ., 2006, 34, 364.

42 S. P. Mulcahy and E. Meggers, Medicinal Organometallic Chemistry, Springer, Berlin Heidelberg, 2010, vol. 32, p. 141. 